Trinity College

Trinity College Digital Repository

Faculty Scholarship

Spring 2005

John Lennon, “Revolution,” and the Politics of Musical Reception

John Platoff

Trinity College, john.platoff@trincoll.edu

Follow this and additional works at: https://digitalrepository.trincoll.edu/facpub

Part of the Music Commons 


\section{John Lennon, "Revolution," and the Politics of Musical Reception}

JOHN PLATOFF

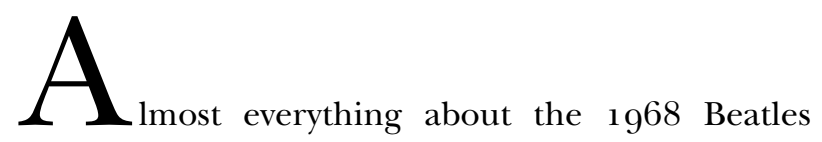
song "Revolution" is complicated. The most controversial and overtly political song the Beatles had produced so far, it was created by John Lennon at a time of profound turmoil in his personal life, and in a year that was the turning point in the social and political upheavals of the 196os. Lennon's own ambivalence about his message, and conflicts about the song within the group, resulted in the release of two quite different versions of the song. And public response to "Revolution" was highly politicized, which is not surprising considering its message and the timing of its release. In fact, an argument can be made that the reception of this song permanently changed the relationship between the band and much of its public.

As we will see, the reception of "Revolution" reflected a tendency to focus on the words alone, without sufficient attention to their musical setting. Moreover, response to "Revolution" had much to do not just with the song itself but with public perceptions of the Beatles. Their rivals the Rolling Stones, the only other rock group of comparable importance in the musical life of the 1960 , released "Street Fighting Man" in the same summer of 1968 . Public reaction to this highly political song was equally passionate yet much more favorable; and this difference

\footnotetext{
A shorter version of this paper, entitled "Why Two 'Revolution's?," was first presented at the International Conference "Beatles 2000" at the University of Jyväskylä, Finland, in June 20oo. I am grateful to Walter Everett, Ruth Montgomery, and Gail Woldu for their valuable advice.
}

\footnotetext{
The Journal of Musicology, Vol. 22, Issue 2, pp. 241-267, ISSN 0277-9269, electronic ISSN 1533-8347. (C) 2005 by the Regents of the University of California. All rights reserved. Please direct all requests for permission to photocopy or reproduce article content through the University of California Press's Rights and Permissions website, at http://www.ucpress.edu/journals/rights.htm.
} 
THE JOURNAL OF MUSICOLOGY

had at least as much to do with the way the bands themselves were perceived as with differences between the songs. A comparison of the two songs, and the way they were understood by audiences, further illuminates the complexities of musical reception in a politicized and polarized time.

\section{John Lennon and "Revolution"}

John Lennon began writing "Revolution" during a two-month stay with the Maharishi Mahesh Yogi in Rishikesh, India, in February-April 1968. His visit, made with the other Beatles and their wives, may have been disappointing in some respects-each of the four Beatles returned to England disillusioned with the Maharishi, if not with all of his teachings-but it was very productive musically. In Rishikesh, Lennon, Harrison, and McCartney composed more than half the 30 songs that eventually made up the acclaimed double album The Beatles, generally known as the White Album, which they recorded from May to October $1968 .^{1}$

"Revolution" was created at a time of uncertainty and change both for Lennon personally and for the world at large. His interest in the avant-garde artist Yoko Ono had deepened from artistic admiration to something much more personal. He invited her as a guest to a Beatles recording session for the first time on February 11. Astonishingly, in light of the fact that he was still married at the time, he considered bringing her with him to India; ${ }^{2}$ and in May, their relationship was consummated both artistically and sexually when Yoko spent the night with Lennon at his home. They made a series of sound-collage recordings later released as Unfinished Music No. 1: Two Virgins (November 1968), then made love for the first time. 3 From that point on the two were inseparable. In fact, Yoko's invariable presence at the Beatles's subsequent recording sessions-breaking a long-standing if unwritten rule that no outsiders were permitted-contributed substantially to the mounting tensions among the band members and their breakup less than two years later. More immediately, it brought to an end Lennon's marriage to Cynthia, which dissolved in acrimony and divorce before the end of the year. 4

1 Walter Everett, The Beatles as Musicians: Revolver through the Anthology (New York: Oxford Univ. Press, 1999), 163.

2 Ibid., $155,161$.

3 Mark Lewisohn, The Complete Beatles Chronicle (London: Pyramid Books, 1992; repr. London: Hamlyn, 2000), 283.

4 Ray Coleman, Lennon: The Definitive Biography, rev. ed. (New York: Harper Collins, 1992), $44^{6}$. 
1968 was also the high point of political unrest in the 6os, a year in which violent uprisings in Europe and the United States commanded widespread attention. It is indeed difficult, more than 35 years later, to appreciate fully how seriously many people at the time feared that a violent revolution might be imminent. 5

Early in the year, the North Vietnamese Tet offensive, a series of coordinated surprise attacks on targets throughout South Vietnam, shockingly dramatized the impossibility of an American victory in Vietnam and raised the intensity of anti-war protests both within and outside the U.S. In February 1968, thousands of students demonstrated in West Berlin; a month later a protest at the American embassy in London culminated in "a pitched battle between police and 100,00o antiwar marchers." 6 Students at Columbia University in New York seized campus buildings to protest both the war and the university's proposed expansion into local neighborhoods, and were attacked by New York policemen, resulting in hundreds of injuries. 7 May saw the start of a lengthy and at times violent student uprising in France, which largely paralyzed much of the country for weeks. President Charles de Gaulle had to dissolve the National Assembly and call for new national elections. ${ }^{8}$ In August, troops from the Soviet Union suddenly invaded Czechoslovakia "to snuff out the freedom and democracy movement heralded in the West as the Prague Spring." 9

In the United States, President Lyndon Johnson, battered by antiwar sentiment, announced in March that he would not stand for reelection. The assassination in April of Martin Luther King, Jr. led to rioting and looting in more than a hundred American cities, with $4^{6}$ deaths and $35^{\circ 0}$ injuries. ${ }^{10}$ In early June Robert F. Kennedy, who was running for the Democratic presidential nomination and who had just won the California primary, was assassinated.

5 Among representative magazine articles of the period one finds the following: "Is Insurrection Brewing in U.S.? An Expert's Appraisal," U.S. News E World Report, 25 December 1967, 32-37; "Can it happen here?" Life, 17 October 1969, 67ff; "Riots: Schools for Revolution? Comparative Study of the French Revolution of 1848 and the Current Negro Revolutions," The Nation, 14 August 1967, 117-18; "Europe on the Brink," National Review, 2 July 1968, 655; "Future of American Politics: Is Revolution Impending?" Current, April 1969, 54-64; "Are We in the Middle of a Revolution?" New York Times Magazine, 10 November $1968,54 \mathrm{ff}$.

${ }^{6}$ Ian MacDonald, Revolution in the Head: The Beatles' Records and the Sixties (New York: Henry Holt, 1994), 226.

7 Arthur Marwick, The Sixties: Cultural Revolution in Britain, France, Italy, and the United States, c. I958-c. I974 (Oxford: Oxford Univ. Press, 1998), 662-63.

8 For a detailed account see ibid., 602-18.

9 Jules Witcover, The Year the Dream Died: Revisiting 1968 in America (New York: Warner Books, 1997), 317 .

10 Marwick, The Sixties, 654-55. 
THE JOURNAL OF MUSICOLOGY

For white, middle-class Americans, the frightening climax to a year of violence came at the end of August with the televised spectacle of Chicago police beating anti-war protesters, delegates, and news reporters alike at the Democratic national convention. Mass protests organized both by the Yippies, led by Abbie Hoffman and Jerry Rubin, and by a variety of anti-Vietnam-war groups provoked a devastating overreaction on the part of Mayor Richard Daley's police. Several nights of violence, including many police attacks on nonviolent demonstrators and innocent bystanders, were reported in newspapers and shown on television across the country. Following the end of the convention Tom Hayden, a leader of anti-war protests, spoke for many when he said that "it may be that the era of organized, peaceful and orderly demonstrations is coming to an end, and that other methods will be needed." ${ }^{11}$ It was against the backdrop of these events that the world first heard the Beatles's "Revolution," which by unhappy coincidence was released in the United States on August 26, the first day of the convention.

As Lennon later made clear, he set out quite deliberately to make a statement about the political turmoil of the time. "I wanted to say what I thought about revolution. I had been thinking about it up in the hills in India and I still had this, you know, God will save us feeling about it, it's going to be all right." ${ }^{12}$ (The lyrics of the song as Lennon and the Beatles initially recorded it in the studio are given in the left-hand column of Ex. 1.) This feeling is most apparent in the refrain at the end of each verse (marked "C"); but many other lines convey Lennon's skepticism about political radicalism and the need for violence, and his conviction that a personal transcendence was necessary. In verse 2 , for instance, he declines to contribute "money for people with minds that hate." In verse 3 , changing the constitution and confronting "the institution [s]" is less important than "chang[ing] your head" and "free[ing] your mind." The mocking reference to people who "go carrying pictures of Chairman Mao" is a swipe at the uncritical enthusiasm in England in 1968 for Mao Tse Tung and his Little Red Book. ${ }^{13}$ And in verse 1 , most crucially for the reception of the song, his response in line 8 to talk about destruction is to say "you can count me out-in."

The song's recording history has four distinct stages, outlined in Table 1. When the Beatles assembled at George Harrison's home in Esher in May 1968 to record demos for most of the songs that would

11 Witcover, The Year the Dream Died, 339.

12 John Lennon, Lennon Remembers: The Rolling Stone Interviews (San Francisco: Straight Arrow Books, 1971 ), 131.

13 Prof. Susan Pennybacker, Trinity College, personal communication. 
EXAMPle 1. "Revolution." Words and music by John Lennon and Paul McCartney. (C) 1968 Sony/ATV Songs LLC. Copyright renewed. All rights administered by Sony/ ATV Music Publishing, 8 Music Square West, Nashville, TN 37203. International copyright secured. All rights reserved

"Revolution 1"

(from the White Album)
"Revolution"

(from the "Hey Jude" single)

$\begin{aligned} & \mathbf{A}^{1} {\left[\begin{array}{l}\text { You say you want a revolution, } \\ \text { Well, you know } \\ \text { We all want to change the world. }\end{array}\right.} \\ & \mathbf{A}^{2}\left[\begin{array}{l}\text { You tell me that it's evolution, } \\ \text { Well, you know } \\ \text { We all want to change the world. }\end{array}\right.\end{aligned}$

B [ But when you talk about destruction,

Don't you know that you can count me out - in.

...count me out.

G $\quad\left[\begin{array}{l}\text { Don't you know it's gonna be all right, } \\ \text { Don't you know it's gonna be all right, }\end{array}\right.$

Don't you know it's gonna be all right.

All right, All right.

$\mathbf{A}^{\mathbf{1}}\left[\begin{array}{l}\text { You say you got a real solution, } \\ \text { Well, you know } \\ \text { We'd all love to see the plan. }\end{array}\right.$

$\mathbf{A}^{2}\left[\begin{array}{l}\text { You ask me for a contribution, } \\ \text { Well, you know } \\ \text { We're all doing what we can. }\end{array}\right.$

We all...

B $\left[\begin{array}{l}\text { But if you want money for people with minds that hate, } \\ \text { All I can tell you is brother you have to wait. }\end{array}\right.$

C $\left[\begin{array}{l}\text { Don't you know it's gonna be all right, } \\ \text { Don't you know it's gonna be all right, }\end{array}\right.$

Don't you know it's gonna be all right.

All right, All right.

[instrumental break]

$\mathbf{A}^{1}\left[\begin{array}{l}\text { You say you'll change the constitution, } \\ \text { Well, you know } \\ \text { We'd all love to change your head. }\end{array}\right.$

We all want to...

$\mathbf{A}^{\mathbf{2}}\left[\begin{array}{l}\text { You tell me it's the } \\ \text { Well, you know }\end{array}\right.$

You better free your mind instead.

B [ But if you go carrying pictures of chairman Mao,

You ain't gonna make it with anyone anyhow.

C $\left[\begin{array}{l}\text { Don't you know it's gonna be all right, } \\ \text { Don't you know it's gonna be all right, }\end{array}\right.$

Don't you know it's gonna be all right.

All right, All right. 
THE JOURNAL OF MUSICOLOGY

later appear on the White Album, "Revolution"'s first two verses were already complete, though the third had not yet been written. In the demo, Lennon concludes by singing the first verse again, and both times in line 8 he sings "you can count me out."

Clearly "Revolution" was very important to Lennon: It was the first song the Beatles worked on when they returned to the studio on May 3o, and it occupied them for all of the first three days of recording before being completed later in June with the overdubbing of a brass section. It is this version, in which Lennon expressed ambivalence in line 8, singing "you can count me out-in," that later appeared on the White Album, released in November, as "Revolution 1." ${ }^{4}$

There was disagreement among the Beatles about what to do with Lennon's new song. Lennon wanted it released "as a single: as a statement of the Beatles' position on Vietnam and the Beatles' position on revolution." ${ }_{15}$ According to Lennon, Harrison and McCartney refused because "it wasn't fast enough"-the recording is markedly slower than Lennon's demo-though he also felt that they resented Ono's presence and his return to a "dominating" position in the group. "After lying fallow for a couple of years, it upset the applecart. I was awake again and they weren't used to it." ${ }^{16}$ But according to Ian MacDonald, McCartney objected to the song as too much of "an overt political statement," ${ }_{17}$ however much he may have argued to Lennon that the song's tempo was a problem.

Unwilling to give up, Lennon called for a remake of the song. In mid July the Beatles recorded a faster and much more raucous version of "Revolution," clearly destined for a single as it was mixed only in

14 Mark Lewisohn, The Beatles Recording Sessions (New York: Harmony Books, 1988), $135-39$.

In the meantime, a free-form jam session on the last six minutes of one take of the song had been cut off and used by Lennon and Yoko Ono as the basis for the soundcollage "Revolution 9," in which the underlying jam from "Revolution 1 " is intermittently audible. Despite the related title, however, "Revolution 9" otherwise plays no part in the reception of the Beatles' "Revolution": It was not heard until the release of the White Album in November 1968, and reactions to it (almost universally negative) focused, appropriately enough, on the work as a piece of electronic music surprisingly included on a Beatles album. For detailed discussions of "Revolution 9" see Everett, Beatles as Musicians, 1 74-78, and Ian Hammond, "Beathoven: Studying the Beatles" (1999), http://www. geocities.com/hammodotcom/beathoven/.

15 David Sheff and ed. by G. Barry Golson, All We Are Saying: The Last Major Interview with John Lennon and Yoko Ono (New York: Playboy Press, 1981; New York: St. Martin's Griffin, 2000), 187. These are Lennon's words from 12 years after the fact; clearly the song is not in any direct way about Vietnam.

16 Ibid.

17 MacDonald, Revolution in the Head, 229. See also Paul Du Noyer, "Ten Minutes That Shook the World: Hey Jude/Revolution: Masterpiece, Turning Point," Mojo, October 1996,59 . 
TABLE 1

A chronology of "Revolution" recordings

\begin{tabular}{|c|c|c|c|c|}
\hline & Demo recording & $\begin{array}{l}\text { First studio recording } \\
\text { ("Revolution 1") }\end{array}$ & $\begin{array}{l}\text { Second studio recording } \\
\text { ("Revolution") }\end{array}$ & $\begin{array}{l}\text { Promotional video } \\
\text { recording }\end{array}$ \\
\hline Location & $\begin{array}{l}\text { George Harrison's } \\
\text { house, Esher }\end{array}$ & $\begin{array}{l}\text { Abbey Road studios, } \\
\text { London }\end{array}$ & $\begin{array}{l}\text { Abbey Road studios, } \\
\text { London }\end{array}$ & $\begin{array}{l}\text { Twickenham Film studios, } \\
\text { London }\end{array}$ \\
\hline Recording date & late May 1968 & May 30-June 25, 1968 & July 10-15, 1968 & September 4, 1968 \\
\hline $\begin{array}{l}\text { Release (or } \\
\text { broadcast) date }\end{array}$ & & $\begin{array}{l}\text { Nov. } 22 \text { (UK) } \\
\text { Nov. } 25 \text { (US) }\end{array}$ & $\begin{array}{l}\text { Aug. } 30 \text { (UK) } \\
\text { Aug. } 26 \text { (US) }\end{array}$ & $\begin{array}{l}\text { Sept. } 19 \text { (UK) } \\
\text { Oct. } 13 \text { (US) }\end{array}$ \\
\hline Text & verses $1-2$ only & complete & complete & complete \\
\hline $\begin{array}{l}\text { Verse } 1 \\
\text { line } 8\end{array}$ & "count me out" & "count me out—in" & "count me out" & "count me out—in" \\
\hline Tempo & $d=124$ & $\cdot=92-104$ & $\cdot=120$ & $\cdot=120$ \\
\hline Guitars & acoustic & $\begin{array}{l}\text { acoustic; occasional } \\
\text { electric guitar chords }\end{array}$ & two distorted electric guitars & $\begin{array}{l}\text { pre-recorded instrumental } \\
\text { track from second studio } \\
\text { recording }\end{array}$ \\
\hline $\begin{array}{l}\text { Other } \\
\text { instruments }\end{array}$ & & $\begin{array}{l}\text { brass section ( } 2 \text { trumpets, } \\
4 \text { trombones) }\end{array}$ & electric piano & [electric piano] \\
\hline Lead vocal & $\begin{array}{l}\text { JL, with occasional } \\
\text { harmony (PM?) }\end{array}$ & JL, double-tracked & $\begin{array}{l}\text { JL, variably double- and } \\
\text { triple-tracked }\end{array}$ & $\begin{array}{l}\text { JL, with occasional } \\
\text { harmony (PM \& GH) }\end{array}$ \\
\hline Back-up vocals & none & $\begin{array}{l}\text { PM \& GH: "bow-oom, } \\
\text { shoo-bee-doo-wah" }\end{array}$ & none & $\begin{array}{l}\text { PM \& GH: "bow-oom, } \\
\text { shoo-bee-doo-wah" }\end{array}$ \\
\hline Stop-time & in part $B$ of each verse & none & in part B of each verse & in part $B$ of each verse \\
\hline
\end{tabular}

Some of the information above is drawn from Everett, The Beatles as Musicians, 173-78; Lewisohn, Beatles Recording Sessions, 135-43; and MacDonald, Revolution in the Head, 223 and 237. 
THE JOURNAL OF MUSICOLOGY

mono. ${ }^{18}$ In this version Lennon returned to his initial stance in line 8, singing "count me out." McCartney's subsequent creation of "Hey Jude," which Lennon agreed was a great song, relegated the faster version of "Revolution" to the B side of the new Beatles single, which as we have seen was released at the end of August.

Yet another version of the song exists, made on September 4 for a promotional video of "Revolution" and "Hey Jude." Here the Beatles recorded new vocal tracks over a taped instrumental track of the faster single version. It includes an electric piano, though there is no piano to be seen in the video. The performance mixes elements of the two previous recordings: Lennon once again changes his stance and sings "out-in," while the back-up "shoo-be-do-wahs," heard on the slower version but not the faster recording, also return (see Table 1). The video of "Revolution" aired both in the U.K. (on September 19) and in the U.S., on the Smothers Brothers Comedy Hour on October $13 \cdot{ }^{19}$

\section{The Politics of Musical Reception}

What the world heard first, then, was "Revolution": the faster, dirtier, distorted version of the song recorded second, and the version in which Lennon sang unequivocally "you can count me out." Critical reaction to the song-whether favorable, from the establishment press like Time magazine, or scathing, from the New Left-focused almost exclusively on the words of the song, and most centrally on the three words of line 8, "count me out." It was the exceptional critic who attempted a response that encompassed both the words and their musical setting; more often the music was either ignored or, at best, treated as a separate entity. Time, for instance, quoted four lines of the song and approvingly summarized its message as an admonition to "radical activists the world over [to] cool it." While noting that the lyrics are sung "over an exhilarating blast of hard rock," the article did not make any connection between the hard rock and what was being sung. ${ }^{20}$ An extended review of "Revolution" and the Rolling Stones's "Street Fighting Man" in the New Left magazine Ramparts measured both songs quite explicitly against a political standard, and Lennon's song, understood and discussed as its words alone, came out much the worse. "'Revolution' is a narcissistic little song ... that, in these troubled times, preaches counter-revolution. ... The chorus of the song is, 'And [sic] you know it's gonna be all right.' Well, it isn't. You know it's not

18 The song was mixed for stereo only in December 1969. Lewisohn, Beatles Recording Sessions, $14^{1-43}$.

19 Lewisohn, Complete Beatles Chronicle, 296-97.

20 "Recordings: Apples for the Beatles," Time, 6 September 1968, 59. 
gonna be all right; the song, in fact, is one of the few Beatles songs that, even artistically, lacks conviction." ${ }_{21}$ More briefly, Richard Merton in the New Left Review called the song a "lamentable petty bourgeois cry of fear." 22

Of course, these two commentaries appeared in overtly radical political publications, and not surprisingly their view of "Revolution" reflected the song's positive or negative value in advancing their political views. Moreover the rage they expressed was heightened by the fact that "Revolution" was released just at the moment of violent police attacks on demonstrators at the Chicago Democratic convention, attacks that seemed to suggest, as many on the left argued, that peaceful protest was no longer possible. But even rock critics struggled, and sometimes failed, to see "Revolution" as the sum of its words and music. Ellen Willis in the New Yorker expressed her unhappiness about the song in an analysis of its lyrics alone:

"Revolution" ... reminds me of the man who refuses a panhandler and then can't resist lecturing him on the error of his ways. It takes a lot of chutzpah for a multimillionaire to assure the rest of us, "You know it's gonna be all right." And Lennon's "Change your head" line is just an up-to-date version of "Let them eat cake."

A comment later in the article separated the meaning of words and music in an almost shocking way: "Aside from the lyrics, the song was fine: good, heavy hard rock. You could even dance to it." 23

A more sophisticated version of this "words bad, music good" view appeared in an essay by Greil Marcus about music, politics, and the protest song. He wrote that

rock 'n' roll is not the polite, quiet, cerebral music of the protest song, and Revolution isn't the strumming of a folk guitar, it's full of the crashing explosions of a great rock ' $n$ ' roll band. There is freedom and movement in the music, even as there is sterility and repression in the lyrics.... Revolution isn't simply a collection of pronouncements and rules.... It is a wild, shouting song that is so immediate and ecstatic that I find myself singing along as my fingers pound out the beat. The music makes me feel happy even though the lyrics depress me. ${ }^{24}$

${ }^{21}$ Susan Lydon, "Would You Want Your Sister to Marry a Beatle?" Ramparts, 3o November 1968, 66 .

${ }^{22}$ Richard Merton, "Comment (Reply to 'for a Rock Aesthetic', by Andrew Chester)," New Left Review, no. 59 (1970): 93 . 61,63 .

23 Ellen Willis, "Records: Rock, Etc.: The Big Ones," New Yorker, 1 February 1969,

${ }_{24}$ Greil Marcus, "A Singer and a Rock and Roll Band," in Rock and Roll Will Stand, ed. Marcus (Boston: Beacon Press, 1969), 96-97. 
THE JOURNAL OF MUSICOLOGY

Unlike the political writers of the New Left, for whom the words equal the song, Marcus understands that the meanings of rock songs are more complex; he struggles to reconcile his enjoyment of "Revolution" with his distaste for what he believes Lennon is saying. Robert Christgau, writing in the Village Voice in 1969, expressed the same struggle, feeling that in an age of social upheaval the political responsibility of rock musicians could not be avoided. Commenting disapprovingly on both Lennon and Bob Dylan, he asserted that "it is puritanical to expect musicians, or anyone, to hew to the proper line. But it is reasonable to request that they not go out of their way to oppose it. Both Dylan and Lennon have, and it takes much of the pleasure out of their music for me." ${ }^{25}$

When the White Album was released in late November, it included the apparently more equivocal "Revolution 1 ," with "count me out-in" in line 8. In MacDonald's words, this version "looked like a recantation of [Lennon's] earlier position and, as such, went down well on campus." 26 But the political activists and critics who preferred "Revolution 1 " for its one crucial added word were responding to the words of the song, not to the song as a whole.

There is, of course, a long tradition of thinking about popular songs more or less exclusively in terms of their words. The reasons for this are not hard to find: Words are concrete, they refer to specific things, and we have an established vocabulary for talking about them. (It is striking that even a serious attempt to address theoretically "the Rhetoric of Popular Music" resulted in an article that discusses lyrics almost exclusively, with no more than brief mentions of musical features of songs. ${ }^{27}$ ) As with any vocal music, however, an understanding of the meaning of a rock song must go beyond the words (or even a juxtaposition of the words and the music, treated as separate entities) to a more comprehensive view, in which the meaning stems not from the words alone but from the way they are expressed in the music.

Research on 6os popular music suggests that far from being crucial, the words are actually incidental to listeners' responses. Two studies of 6 os protest songs found that the great majority of teenagers familiar with the songs did not know what the lyrics meant. In 1965 , during the height of popularity of Barry McGuire's "Eve of Destruction," a highly controversial song that was kept off the air by many radio stations, nearly half of San Francisco State College students who had

25 Robert Christgau, "Rock 'n' Revolution," in Any Old Way You Choose It: Rock and Other Pop Music, I967-I973 (Baltimore: Penguin Books, 1973), 100.

${ }_{26}$ MacDonald, Revolution in the Head, 227.

27 Robert L. Root, Jr., "A Listener's Guide to the Rhetoric of Popular Music," Journal of Popular Culture 20 (1986): $15^{-26}$. 
heard the song and were supplied the lyrics "either would not or could not interpret the meaning of the song correctly." 28 In another study involving 8th- and 11 th-graders in Michigan, only 10 to 30 percent could provide accurate interpretations of the tested songs that they reported having heard. In the unequivocal words of the researchers, "the vast majority of teenage listeners are unaware of what the lyrics of hit protest songs are about." ${ }^{9} 9$ In 1970 sociologist Norman Denzin, reflecting on studies like these, argued that since "in popular music . . . listeners focus on the beat and not the words," the meaning of songs for pop listeners cannot be reduced to the lyrics alone. $3^{\circ}$

So while to the New Left Lennon's song was a sell-out, and its line "you can count me out" particularly infuriating, it does not follow that most listeners attended to the words as carefully as political activists and rock critics did. Many of them, surely, were responding to the music. And a closer look at the musical settings of "Revolution 1," the Beatles's first rendering of the song, and "Revolution," reveals that the differences go far beyond the words "count me out-in." ${ }_{11}$

The song has three verses, each of which ends with a refrain, a form familiar from many other Beatles songs. Here the verse is an $\mathrm{A}^{1} \mathrm{~A}^{2} \mathrm{BC}$ structure, as shown in Example 1.32 Each of the first three parts of the verse is irregular in length, containing a $\underset{\mathbf{4}}{\boldsymbol{2}}$ measure unobtrusively inserted within the prevailing ${ }_{\mathbf{4}}^{\mathbf{4}}$ meter.33 The heart of "Revolution 1 " is Lennon's solo vocal, backed up by his acoustic rhythm guitar, McCartney's bass, and Starr's drums, along with McCartney and Harrison singing back-up vocals (the "shoo-be-doo-wah"s). But as is the case in so many Beatles recordings, the group makes subtle changes in texture both from one verse to the next and between the sections of each verse, nearly always by adding new elements. In the first verse the "shoo-bedoo-wah" appears only in part $\mathrm{C}$, the refrain (at 1:00); but in later

${ }_{28}$ R. Serge Denisoff and Mark H. Levine, "Brainwashing or Background Noise: The Popular Protest Song," in The Sounds of Social Change, ed. R. Serge Denisoff and Richard A. Peterson (Chicago: Rand McNally, 1972), 217.

${ }^{29}$ John P. Robinson and Paul M. Hirsch, "Teenage Response to Rock and Roll Protest Songs," in The Sounds of Social Change, ed. Denisoff and Peterson, 226, 231.

$3^{\circ}$ Norman K. Denzin, "Problems in Analyzing Elements of Mass Culture: Notes on the Popular Song and Other Artistic Productions," American Journal of Sociology 75 (1970): 1036 .

${ }_{31}$ "Revolution 1" is on The Beatles (the White Album) (Parlophone CDP 746443 2), $\mathrm{CD} 2$ 2, track 8; "Revolution" is on The Beatles: Past Masters, Volume 2 (Parlophone CDP 7 $\left.90044^{2}\right)$, track 8.

$3^{2}$ The texts are given as actually heard on each recording; that for "Revolution 1" does not correspond exactly with the text as printed in the booklet for the White Album.

33 The lengths of the sections are thus $61 / 2,61 / 2$, and $51 / 2$ measures. In the A sections the half-measure comes at the words "Well, you"; in the B section the halfmeasure coincides with the strongest syncopations of the song, at "count me out." 
THE JOURNAL OF MUSICOLOGY

verses it occurs in the A sections as well, along with harmonized singing of the melody. An added brass section (two trumpets and four trombones) first appears in the $\mathrm{B}$ section of the first verse and takes an increasingly active role thereafter; by the third verse (from 2:25) it is playing whimsical syncopated chords throughout. A distorted electric guitar is heard playing distant chords in the first refrain and then contributes syncopated chords or short licks with increasing frequency as the song progresses.

In "Revolution 1" the pace is relaxed, the most prominent instrument the easy strumming of an acoustic rather than an electric guitar, and Lennon's double-tracked vocal is unusually smooth and mellow. At least part of it, in fact, was recorded with him singing lying on his back on the studio floor. ${ }^{34}$ And the melody itself forms a graceful arch, rising up a full octave to the word "revolution" in the first line before descending again to the fifth scale degree with which it begins. It is a pentatonic tune, one that would not be out of place in a folk song or a gentle romantic ballad. If there is a revolution going on, this music is clearly not anywhere near it (though Walter Everett points out that the revolution is "sizzling in the distance," in the occasional electric guitar chords) 35 . On the contrary, Lennon is preaching to us about revolution from a place of calm and safety-perhaps even his retreat at Rishikesh. In this track's musical world, Lennon's ambivalence about counting him "out-in" makes less of an impression than the repeated assurances of the refrain, “don't you know it's gonna be all right." Each time, all but the final two words of the line are sung in a falsetto that suggests light-hearted certainty. As the song progresses the music becomes more playful, even jaunty. The third refrain concludes with a single measure of $\mathbf{8}$ that shockingly interrupts the ${ }_{\mathbf{4}}^{\mathbf{4}}$ flow of the song (at $3: 24$ ). In the coda and long fade-out (from 3:30), the brass section bounces along with irreverent syncopations as the back-up singers continue to "shoobe-doo-wah," and Lennon repeats "alright, alright" and offers some apparently sexual panting that undermines whatever seriousness he intended earlier in the song.

The single version of "Revolution" could hardly be more different musically. The tempo is more than $20 \%$ faster (see Table 1 ), and the sound is raucous and dirty, dominated by Lennon's and Harrison's highly distorted electric guitars. $3^{6}$ Lennon's vocal begins with a wild

34 Lewisohn, Beatles Recording Sessions, 136.

35 Everett, Beatles as Musicians, 174.

${ }_{36}$ The guitar distortion was, in producer George Martin's words, "done deliberately because John wanted a very dirty sound on guitar and he couldn't get it through his amps." It was created by putting the guitars through the recording console, thus overloading the pre-amp on the mixing board. The Martin quotation is in Nicholas Schaffner, 
high scream. In this version of the song, the revolution swirls all around us from the very beginning; Lennon's words come not from a safe place of retreat but from the heart of the chaos. His delivery of the graceful melody is flat, cold, and pushed far forward in the mix. As the song progresses there are several other notable changes from the earlier version. The B section of each verse, where many of the crucial words occur, is a savage and heavily rhythmic "stop-time," with the guitars suddenly silent (as at 0:35); the strong syncopations of the half measure at "count me out" are emphasized energetically. In the refrain, Lennon sings the reassuring falsetto line "don't you know it's gonna be all right" only once, contenting himself thereafter with repeating the words "all right." His lead vocal is recorded quite differently in this version: Not only is it more aggressive and cold, but the vocal is double-tracked and at times triple-tracked in an audibly strange way, with the tracking changing from one syllable to the next within single words (in line 4 , for example, there is an awkward overdub on the third syllable of the word "evolution," at 0:22). The effect is of an unreliable radio transmission from the middle of a riot or a war zone. Perhaps most important, both the playful "shoo-be-doo-wah" back-up vocals and the jaunty brass section have disappeared altogether. The sound world of this track continues to be intense and frightening, "formed of distortion and sonic abrasion." 37 There is an instrumental break after verse 2 (at 1:54), and there and in the coda the session musician Nicky Hopkins plays wild solos on electric piano. The song rushes headlong toward its final chord, and Lennon's last "all right" is almost as intense as the scream with which he begins.

Far from being removed or preachy, the single track of "Revolution" is urgent, immediate, and even desperate. It is "Revolution 1 " that philosophizes from a quiet armchair and gives the impression of being above it all. Michael Wood points to this quality in a review of "Revolution $1 "$ from December 1968.

The Beatles ... tell us that it's going to be all right-we can avoid all the violence and the hatred. We don't need a revolution. Now this may be right or wrong, but either way it's an absurd statement, if the Beatles intend it flatly. So listen to them. There is an echo of the Beach Boys in their voices as they sing, softly, "it's gonna be (shoo-beedoo-wah) all right ..." It's not an irony, though, it's a joke. They don't mean that it's not gonna be all right. They mean that statements about

The Beatles Forever (Harrisburg, Pa.: Cameron House, 1977), 108-9. See also Lewisohn, Beatles Recording Sessions, 142.

37 Devin McKinney, Magic Circles: The Beatles in Dream and History (Cambridge: Harvard Univ. Press, 2003), 222. 
THE JOURNAL OF MUSICOLOGY

whether it is or it isn't are all part of that political crap they dislike so much, the real show business of the world. $3^{8}$

Like Wood, I hear in "Revolution 1" an unwillingness to take the hard questions seriously-a kind of smugness, a sense of parody and "we're above it all." And this quality arises primarily from the musical arrangement, especially the back-up vocals and the brass section. Had the New Left been listening to the music as well as the words, this smugness would surely have increased their fury far more than the change to "count me out-in" might have placated them. In this sense, in fact, they preferred the wrong version of the song.

\section{Mick Jagger and "Street Fighting Man"}

For two reasons, "Street Fighting Man" and its reception form a crucial part of the story of "Revolution." The first is simple: Besides the Beatles, no other group loomed as large in the musical life of the $1960 \mathrm{~s}$ as the Rolling Stones. From the beginnings of the group in 1962-63 they had worked to create an aura of danger, of bohemian scruffiness and barely suppressed violence. In Greil Marcus's words, they were the "Left" to the Beatles's "Center"; 39 they were seen as a more radical alternative voice, both by those who preferred the band and those who did not. Second, the timing of the American release of "Street Fighting Man" and its overtly political content ensured that the two songs would become paired in the consciousness of the public and explicitly compared in the writings of critics.

As was the case for Lennon and "Revolution," Mick Jagger and his bandmates in the Stones faced disturbing personal and political challenges in the months leading up to the recording of "Street Fighting Man.” Jagger, Keith Richard, and Brian Jones were all arrested and convicted of drug charges in 1967 as part of a politically motivated crackdown on drug use by leading pop musicians. While the prison sentences of all three were ultimately quashed, the arrests and subsequent legal battles had a radicalizing effect on the members of the band.

On 12 February 1967 , police raided a party at Keith Richards's house at Redlands, based on a highly suspicious "anonymous" tip about drug use. Both Richards and Jagger were arrested, and after being found guilty at trial in June were sentenced to ludicrously excessive sentences (Richards was sentenced to a year in prison for permitting can-

$3^{8}$ Michael Wood, "Four Beatles, Five Stones: Etc.," Commonweal, 27 December 1968, 439. The italics are Wood's.

39 Greil Marcus, "The Beatles," in The Rolling Stone Illustrated History of Rock E Roll, ed. Anthony DeCurtis and James Henke with Holly George-Warren; orig. ed. Jim Miller (New York: Random House, 1992), 217. 
nibis to be smoked on his property; Jagger was given three months in prison for possession of four pep pills, which he had acquired legally in Italy). By the end of July, after public outcry and even an editorial in the London Times denouncing the sentences, Richards's conviction was overturned and Jagger's sentence reduced to probation. During the trials and prior to the filing of their appeals, both men spent three nights in prison. During the same period Brian Jones was arrested and convicted for possession of cannabis; his nine-month sentence was also ultimately set aside. A subsequent drug arrest of Jones, on 21 May 1968, eliminated any possibility of the Stones' planned American tour that year. $4^{\circ}$

The drug busts were widely perceived as politically motivated, and it was understood that the Rolling Stones in particular were being targeted. (Paul McCartney was among those outraged at the treatment of the band, in sharp contrast to the "kid-glove handling of the Beatles; particularly in view of the fact that the Fab Four's lifestyle was equally well known at the time." ${ }^{11}$ ) They certainly had a radicalizing effect on Jagger, who had not been actively involved in politics during his preRolling Stones years at the London School of Economics. Tom Driberg, a Labor Party MP sympathetic to radical causes, got to know Jagger well during a series of conversations about politics and even urged him to run for office, a possibility that Jagger at one point considered seriously. $4^{2}$

The most public expression of Jagger's political feelings came on 17 March 1968, when he joined the massive anti-Vietnam War demonstration in front of the American Embassy in Grosvenor Square, London. Part of a crowd of tens of thousands, at first Jagger was not noticed, and he linked arms with a young man on one side and a young woman on the other as the mob tried to smash their way through police lines and into the embassy. ... But then he was recognized; fans demanded autographs; newspapermen scuffled with one another to interview him, to fire off their flashguns in his face. He fled, realizing bitterly that his fame and wealth precluded him from the revolutionhe was a distraction, not a leader.43

$4^{\circ}$ Information in this paragraph is drawn from James Karnbach and Carol Bernson, It's Only Rock 'N' Roll: The Ultimate Guide to the Rolling Stones (New York: Facts on File, 1997), 17-2 1; Tony Scaduto, Mick Jagger: Everybody's Lucifer (New York: David McKay, 1974), 260; and Philip Norman, Symphony for the Devil: The Rolling Stones Story (New York: Simon \& Schuster, 1984), 256. A. E. Hotchner, in Blown Away: The Rolling Stones and the Death of the Sixties (New York: Simon and Schuster, 1990), 229-65, presents an extended account of the drug raids and trials, including excerpts from the trial transcripts.

$4^{1}$ Karnbach and Bernson, It's Only Rock 'N' Roll, 18.

$4^{2}$ Scaduto, Mick Jagger, 26o, 265-68; Norman, Symphony for the Devil, 256-57.

43 Tony Sanchez, Up and Down with the Rolling Stones (New York: William Morrow, 1979), 122. 
THE JOURNAL OF MUSICOLOGY

Jagger's experience during the American Embassy demonstration was crucial to the creation of "Street Fighting Man," which actually began life as a quite different song entitled "Did Everybody Pay Their Dues." 44 An early instrumental backing track (referred to as "Primo Grande") resulted from recordings made by Keith Richards and Charlie Watts on Richards's low-fidelity cassette recorder at his home in late 1967. "Pay Your Dues" was recorded in March 1968, using the cassetterecorded backing track, and was actually scheduled for release in May as the band's new single (it was announced in the trade press on May 4). However, a week later the band withdrew the song and replaced it with "Jumping Jack Flash," released in late May, which became one of the Stones' most successful singles.

In the meantime, Jagger went back to "Pay Your Dues," replacing the vocal track with one sung to the lyrics of "Street Fighting Man." The recording of the new version took place in London in mid May and was completed in Los Angeles in July. For unknown reasons the song was released as a single only in the United States. It also appeared on the Stones album Beggar's Banquet, which however was not released until 6 December 1968 (simultaneously in the U.S. and the U.K.).

For reasons both of subject and of timing, then, "Street Fighting Man" was inevitably a foil for "Revolution": It is another overtly political song, a response on the part of its creators to personal and political struggles, and it was being heard in the United States at the same time as the Beatles single, and during the Chicago convention. Yet it was treated by the critics in an entirely different way.

Listening to the song confirms that this is great rock and roll, full of energy and drive. 45 The music's heavy-footed marching feel perfectly illustrates the "marching, charging feet" of the lyrics (see Ex. 2). It is more constant, less varied than "Revolution," and maintains its forward thrust and full sound throughout. Like "Revolution," "Street Fighting Man" is cast in a verse-refrain structure $\left(\mathrm{A}^{1} \mathrm{~A}^{2} \mathrm{~B}\right)$. In the opening lines of each verse $\left(\mathrm{A}^{1} \mathrm{~A}^{2}\right)$, Jagger's vocal melody alternates relentlessly between tonic and fourth scale degree, supported by the band's heavy backbeat. In the refrains (as at 0:32) the texture becomes fuller and thicker, enriched by a sitar $4^{6}$ and other instrumental sounds. Here the band sustains the dominant chord until the final note of the refrain, and Jagger's melodic line does nothing more than arpeggiate the dominant chord over and over. In both parts of each verse, the melody does

44 Much of the information in this and the next paragraph comes from Karnbach and Bernson, It's Only Rock 'N' Roll, 233-37.

45 It is found on the Rolling Stones, Beggars Banquet (Abkco 95392), track 6.

$4^{6}$ Karnbach and Bernson, It's Only Rock ' $N$ ' Roll, 234. According to Walter Everett (personal communication), the instrument is not a sitar but a tamboura. 
little to separate itself from the steady, heavy march of the instruments. Nor is there much musical variety from verse to verse-only in the third verse is there a small change, when the two tracks of Jagger's vocal (which is double-tracked throughout) separate to provide vocal harmony on the refrain (at 2:08). Taken as a whole, the music of "Street Fighting Man" is powerfully uniform, driving forward continuously without hesitation through the entire track.

But listening to the song also reminds us that the words are virtually incomprehensible. Mick Jagger was quoted once as saying that in rock and roll, the lyrics shouldn't be too easy to hear, and his maxim certainly applies to this song. (In fact, generations of listeners have insisted that line 2 reads "fighting in the streets," though with headphones one can hear that he sings "rising.") But a close look at those lyrics suggests a cop-out. "Yes, revolution is at hand," Jagger seems to be saying, "but I'm in sleepy old London, and all I can do is sing in a band." In particular, the last line of the refrain, "there's just no place for a street fighting man," suggests that somehow it just wouldn't do to get out of line. 47

Yet not only did critics embrace this song, they actually held it up as the healthy-one might say "politically correct"-alternative to "Revolution." Ellen Willis, who criticized Lennon's song for its lyrics alone, wrote this about Jagger's:

Taken together, the words of "Street Fighting Man" are innocuous, but somehow the only line that comes through loud and clear is "Summer's here, and the time is right for fighting [sic] in the streets." Then, there's the heavy beat and all that chaotic noise in the background. So Mick leaves no doubt where his instincts are. $4^{8}$

Her claim seems to be that the music makes the words all rightexactly what she denied in the case of "Revolution," which of course also has a "heavy beat and all that chaotic noise in the background."

Greil Marcus offers a more sophisticated reading, as he did in the case of Lennon's song. To him, "Revolution" is a closed book: It preaches, it tells us what to think. "Street Fighting Man," on the other hand,

won't do our thinking for us.... [The Stones] aren't giving orders, but describing a very simple situation that is possessed by an unexpected complexity. The tension rises, created by the band, as it fights the doubts of the lyrics with tough musical emotion, the tension created

47 For a reading more sympathetic to Jagger, one that gives him credit for having doubts, see Jon Wiener, Come Together: John Lennon in His Time (New York: Random House, 1984; repr. Urbana: Univ. of Illinois Press, 1991), 65-66.

$4^{8}$ Willis, "The Big Ones," 6o-61. 
THE JOURNAL OF MUSICOLOGY

EXAmple 2. "Street Fighting Man." Written by Mick Jagger, Keith Richards. Published by ABKCO Music, Inc.

\section{"Street Fighting Man"}

$\mathbf{A}^{\mathbf{1}}$ [ Everywhere I hear the sound of marching, charging feet, boy

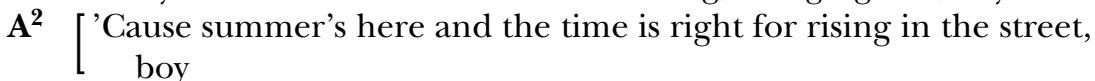
Well then what can a poor boy do
'Cept to sing for a rock 'n' roll band
B 'Cause in sleepy London town
There's just no place for a street fighting man
No

$\mathbf{A}^{\mathbf{1}} \quad$ [ Hey! Think the time is right for a palace revolution

$\mathbf{A}^{2}$ [But where I live the game to play is a compromise solution

Well then what can a poor boy do

'Cept to sing for a rock 'n' roll band

B 'Cause in sleepy London town

There's just no place for a street fighting man
No

$\mathbf{A}^{1} \quad$ [Hey! Said my name is called disturbance

$\mathbf{A}^{2}$ [ I'll shout and scream, I'll kill the king, I'll rail at all his servants

Well then what can a poor boy do

'Cept to sing for a rock 'n' roll band

B 'Cause in sleepy London town

There's just no place for a street fighting man

No

Get down

by Jagger's singing, angry and self-deprecating at the same time....

The song [doesn't] give answers. 49

I find it fascinating that the critics were willing to give the Rolling Stones so much credit, to stamp their revolutionary passports. And they weren't the only ones: Radio stations in Chicago, Berkeley, and elsewhere banned "Street Fighting Man" from the airwaves, though "Revo-

49 Marcus, "A Singer," 101-3. 
lution" was heard over and over. Where I see a cop-out, people in 1968 saw nobly revolutionary (or dangerously revolutionary) fervor.

\section{Radio Airplay and the Record-Buying Public}

The responses by critics to "Revolution" and "Street Fighting Man," which so often cited the two songs together, might suggest that they achieved a comparable commercial success. In fact this was far from the case. "Revolution" appeared on the national "Top 100" charts in the United States for 11 weeks, reaching a high of \#12 on the Billboard chart. By contrast "Street Fighting Man" charted nationally for only six weeks and never exceeded a Billboard high of \# $48.5^{\circ}$ But this comparison too is oversimplified and misleading. In different ways each song was an anomalous case- "Revolution" because it was the B-side of "Hey Jude," one of the Beatles' most successful singles ever, and "Street Fighting Man" because it was removed from the playlists of most American radio stations in early September 1968.

In general, information on the popularity and commercial success of a single can be gleaned not only from the weekly "Top 100" singles charts in national magazines like Billboard, Cash Box, and Record World, but from the informative "Top 30" or "Top 40" charts produced by local radio stations across the country. The charts do not, as might be imagined, simply reflect comparative record sales; they frequently factor in other elements as well. For example, station KQV in Pittsburgh reported that its top $4^{\circ}$ list "is selected each week by KQV Radio from reports of all record sales gathered from leading record outlets in the Pittsburgh area, requests, music information tabulated nationally, and other sources available to KQV." ${ }^{1}$

Because a song's position on a "Top Hits" chart did not depend on record sales alone, it was possible for the A-side and B-side of the same record to be listed independently, as happened for "Revolution" and "Hey Jude" in the Billboard, Cash Box, and Record World charts (as well as in a few local radio station charts; most considered the two songs together, or listed only "Hey Jude," the A-side). In Billboard and Cash Box, "Revolution" made the Top 100 on September 14, roughly two weeks after its American release; it reached a high position of \#1 1 (Cash Box) or \#12 (Billboard), and lasted on each list for 10 or 11 weeks. In Record World the song reached a high of \#2, immediately behind "Hey Jude" ${ }^{2}$;

$5^{\circ}$ Information on Billboard and Cash Box here and in the following paragraphs comes from Billboard, 7 September-23 November 1968, and Cash Box, 31 August-16 November 1968 .

${ }^{5^{1}}$ From the Top 40 survey of 7-13 October 1968. The KQV surveys are at Jeff Roteman, "Radioville," http://radioville.cjb.net/.

$5^{2}$ Bruce Spizer, The Beatles on Apple Records (New Orleans: 498 Productions, 2003), 32. 
THE JOURNAL OF MUSICOLOGY

and this was also true in some local markets, such as the top-40 " $\mathrm{Hit} \mathrm{Pa}-$ rade" of WLS in Chicago. 53

Since it was obviously impossible to tell whether record-buyers were spending their money on "Hey Jude," "Revolution," or (quite reasonably) both, sales figures offer no insight into the relative popularity of the song in the pop singles market.54 What can be said with more confidence is that "Revolution" was widely heard. The top-hits charts of local radio stations served not only as guides to what was popular at a given moment but to what the stations actually played. Cash Box, in a weekly feature called "Radio Active," gave figures showing what percentage of stations nationally had added a new single to their playlists. In the week ending 4 September 1968, "Revolution" was being played by $34 \%$ of stations; a week later the figure jumped to $95 \%$.

Exactly when "Street Fighting Man" was released in the United States is something of a mystery. Karnbach and Bernson give the release date as 30 August 1968,55 but it was clearly being heard before then (whether or not it was available for sale). The Cash Box "Radio Active" listing indicates that the song was being played on 29\% of American stations by the week ending August 14. By three weeks later, in the week ending September 4 , it had made the playlists of no less than $98 \%$ of all stations surveyed. Moreover, "Street Fighting Man" had appeared on the "Fabulous 57" chart of WMCA in New York by August $14 ;^{5}$ by the end of the month it had charted in a number of leading pop music station playlists before appearing on the national charts on September 7 .

Then, in the aftermath of the riots and beatings at the Chicago convention, “'Street Fighting Man' was denounced as plain incitement

53 Information here and below on local radio station charts is drawn from a number of Internet sites that have posted chart information from North American radio stations. For WLS see Bill Danning, "Oldiesloon: Radio and Music Memories from the 5o's, 6o's \& 7o's," http://www.oldiesloon.com/, which gives charts for stations in Chicago, Los Angeles, and Minneapolis/St. Paul, among others. Plannine, "Classic Top 3o," http://www. ct3o.com/, has charts for stations in Detroit and San Diego. Sheldon Swartz, "Top4oSurveys.com," http://top4osurveys.com/, gives charts for WRKO Boston and many other stations. The "Airheads Radio Survey Archive," http://www.las-solanas.com/ arsa/index.php, has posted more than 2800 charts from more than 600 stations. Charts for WABC New York are found at Allen Sniffen, "Musicradio 77 WABC," http://www. musicradio77.com/; those for WMCA New York at Allen Sniffen, "WMCA: Fabulous 57," http://musicradio.computer.net/wmca/.

54 However, Walter Everett (personal communication) points out that in reaching \#1 2 nationally "Revolution" did far better than the group's three previous B-sides. These were "Baby You're a Rich Man" (reached \# ${ }_{34}$ ), "I am the Walrus" (\# $\left.{ }_{5} 6\right)$, and "The Inner Light" (\#96). These chart figures are found in Everett, The Beatles as Musicians: The Quarry Men through Rubber Soul (New York: Oxford Univ. Press, 2001), 207-10.

55 Karnbach and Bernson, It's Only Rock 'N' Roll, 279. It is given as 31 August 1968 in Bill Wyman, with Richard Havers, Rolling with the Stones (New York: DK Publishing, 2002), 309.

$5^{6}$ Sniffen, "WMCA: Fabulous 57." 
to further violence and banned by every radio station in the Chicago area, together with dozens more across the continent." 57 The ban, reported in Melody Maker on September 7 in a story datelined "New York, Monday [Sept. 2]," ${ }_{5}^{8}$ is reflected in the "Top 40" charts of a number of North American radio stations. The song never appeared at all in the charts of stations in Chicago (WLS and WCFL) and many other cities.59 On other local charts, "Street Fighting Man" rose from week to week, then suddenly disappeared, without the usual downward trajectory that marked the gradual decline of a pop song's popularity. ${ }^{6}$

The effect of the ban is notable in the national charts as well. "Street Fighting Man" charted for only six weeks at Cash Box and Billboard, reaching a high of $\#_{30}$ and $\#_{4} 8$ respectively, before disappearing after the week of October 12-again without the usual gradual downward drift.

What all this means in terms of the song's effect on the American audience is unclear. Marcus reports that in the Bay Area in early September it "was invisible except for the title," though still much discussed: "it is amazing how people can speculate on a song they've never even heard." ${ }^{1}$ It is possible that in other parts of the country listeners were unable to hear the song, though there is no evidence it was withdrawn from record stores. In any case, the American release of the Stones album Beggar's Banquet in December 1968, with "Street Fighting Man" the opening track on the B-side, rendered the issue moot. Many of the critical comparisons between the song and "Revolution" cited in this article, in fact, appear in the context of a broader discussion of Beggar's Banquet and the White Album, which as mentioned was released in the United States at the end of November.

\section{Two Songs, Two Receptions}

What accounts for the sharp difference in critical reaction to the two songs? The intrinsic differences between them are only part of the story. There are also extrinsic factors, chief among them the set of assumptions and beliefs about an artist or a band that listeners bring to

57 Norman, Symphony for the Devil, 271.

$5^{8}$ "Stones Disc Ban in U.S.," Melody Maker, 7 September 1968.

59 These included WDGY, Minneapolis/St. Paul; KIMN, Denver; KQV, Pittsburgh; WQAM, Miami; and perhaps most important, WABC, New York. See n53.

6o On KGB, San Diego, for example, the song charted for six weeks, rising to a high of \#14 on September 18 ; then it disappeared. Some version of this pattern can be noted also at KNJ, Los Angeles; WAVZ, New Haven; WRKO, Boston; CKLW, Detroit/Windsor; and WKNR, Detroit. In each case the final chart appearance of "Street Fighting Man" fell between Sept. 7 and Sept. 17. See $n_{53}$.

61 Marcus, "A Singer," 98. 
THE JOURNAL OF MUSICOLOGY

any new song. It is clear that these assumptions and beliefs interact with and influence what the song itself is perceived by each listener to mean.

To begin with the intrinsic, i.e. the words and music of each song: Lennon's words to "Revolution" are clear and easy to understand (in fact they are remarkably so, by comparison to some of Lennon's other important Beatles songs like "Strawberry Fields Forever," "A Day in the Life" [written with McCartney], or "I am the Walrus"). To Marcus, they "delivered a straightforward message, a strict command ... denying the imagination in favor of a tangible opinion." 62 By contrast, as we have seen, Jagger's lyrics to "Street Fighting Man" signal a dilemma: On the one hand "the time is right for rising in the street," but on the other there is no place in "sleepy London town ... for a street fighting man." So the protagonist, alive at the right time but stuck in the wrong place, can do no better than to "sing for a rock 'n' roll band." Marcus and the other critics cited above are surely right in claiming that unlike "Revolution," "Street Fighting Man" doesn't tell us what to think.

But Lennon's lyrics, with their clearer meaning, are also sung more distinctly. Even in the dirtier and more frightening of the two musical settings of "Revolution," the single, Lennon's soaring melody and the words he sings to it come through clearly. Jagger's approach is quite the opposite: Both his deliberately lazy diction and the surrounding instrumental sounds of "Street Fighting Man" obscure the lyrics-nearly all the critics who write about the song have noted how few of the words can be heard clearly. In a 1969 review Jon Landau describes Jagger as "fighting to be heard over the din of the instruments," and he goes on to misquote the first line of the song ("the sound of charg-ing, march-ing peo-ple"). ${ }^{63}$ This difference has two important effects. First, because the lyrics of "Street Fighting Man" are so much harder to hear, the music dominates people's response to the song more than with "Revolution." Second, the fact that the message of the words of "Street Fighting Man" is both less clear in itself and less audible on the recording means that there is more room left for individual interpretation of that message than is true for Lennon's song.

Conversely, in musical terms it is the Stones song that is clearer, or at least less mixed in its message. "Street Fighting Man" is a marching song in an unvarying $\underset{\mathbf{4}}{\mathbf{4}}$ meter; it sounds like an anthem. ${ }^{64}$ As we have seen, Jagger's melody has little variety or melodic range, and for long stretches it simply alternates between the tonic and fourth scale degree.

62 Ibid., 96.

63 Jon Landau, "Beggar's Banquet," Rolling Stone, 4January 1969, 12-13. The italics are Landau's.

64 Professor Fred Pfeil, Trinity College, personal communication. 
The instrumental backing of the song provides a constant, relentless rhythmic drive. As a whole, the song's music conveys a sense not of revolution but of marching - the "marching, charging feet" of its first line.

But the music of "Revolution" cannot be characterized so simply. On the one hand there is Lennon's graceful, arching melodic line and his falsetto singing in the refrain. (While these features are more important in the mellow "Revolution 1 " performance, they are still prominent in the single version.) These seem to support Lennon's message that "it's gonna be all right," that one can turn away from violence and from "people with minds that hate." On the other hand there is the harshness and the pain of the single. This was an astonishing sound for 1968, predating the heavy metal explosiveness of Led Zeppelin and other bands. Its sonic distortions, its screams, the wildly energetic piano playing of Nicky Hopkins-everything together produces a raw, abrasive track that goes far beyond the Stones' single in desperation and intensity. ${ }_{5}$ In a sense this music is the sound of the revolution itself: Listeners find themselves in the middle of the chaos and violence. Yet critics at the time, far from recognizing this quality as a key feature of the recording, did not comment on it at all. ${ }^{66}$

I have already made the obvious point that the meaning of a song does not simply equal the meaning of its lyrics. But of course even the words and music together do not fully create the meaning of a song: That meaning is really "the sense listeners [make] of songs for themselves," 67 and listeners bring to any new song by a favorite band an already formed set of beliefs. In Simon Frith's words, "our response to songs is determined in part by our assumptions about their performers, and one function of lyrics is to meet these assumptions." 68 By 1968, listeners all over the world thought they knew who the Beatles were and what their views were. (For one thing, the members of the group, and

$6_{5}$ See McKinney, Magic Circles, 22 1-22.

66 An amusing exception is provided by Chris Welch, "Beatles New Single: Yes, They Do Grow on You!," Melody Maker, 31 August 1968. After several paragraphs on "Hey Jude," the A-side, Welch comments on "Revolution" in a single sentence: "The B side is a fuzzy mess, and best forgotten."

${ }_{7}$ Simon Frith, "Why Do Songs Have Words?," in Music for Pleasure: Essays in the Sociology of Pop (New York: Routledge, 1988), 119. See also Denzin, "Problems in Analyzing Elements," 1035-36. A provocative study of "All You Need is Love" in 1996 showed that college students at that time read various meanings into the song that cannot be found anywhere in its lyrics. See Arnold S. Wolfe and Margaret Haefner, "Taste Cultures, Culture Classes, Affective Alliances, and Popular Music Reception: Theory, Methodology, and an Application to a Beatles Song," Popular Music and Society 20 (1996), esp. 139-45.

68 Simon Frith, Sound Effects: Youth, Leisure, and the Politics of Rock 'n' Roll (New York: Pantheon Books, 1981), 36. 
THE JOURNAL OF MUSICOLOGY

Lennon in particular, had been speaking out against the Vietnam war since 1966.) They were widely seen by young people as cultural leaders, setting the direction for social change and showing others where to follow. In writing about "Revolution," Marcus put this quite explicitly:

A lot of the people were mad at the Beatles because their "politics" didn't agree with ours. We felt tricked, because we had expected the Beatles to be our spokesmen (whoever "we" were), to say what we wanted to hear, what we wanted to learn about. We had taken the Beatles for granted, and if we felt tricked, it was probably our fault. ${ }^{69}$

Conversely, the largely favorable reception of "Street Fighting Man" had much to do with the established reputation of the Stones: not only as "musical anarchists, harbingers of chaos" in the words of Susan Lydon, $7^{\circ}$ but as sophisticated thinkers, standing in an ironic relationship to their own songs. This is an argument often encountered in writing about the Stones: that their overtly sexist songs, for example, must be read as illustrating a critical attitude towards sexism.

"Under My Thumb," "Stupid Girl," "Back Street Girl" or "Yesterday's Papers" are about sexual exploitation.... The enormous merit-and audacity - of The Stones is to have repeatedly and consistently defied what is a central taboo of the social system: mention of sexual inequality. They have done so in the most radical and unacceptable way possible: by celebrating it. The light this black beam throws on the society is too bright for it. Nakedly proclaimed, inequality is de facto denounced. $7^{11}$

The shaky intellectual basis of this claim-which is most often simply asserted, as above, rather than argued-seems obvious. And yet a willingness to credit the Stones with a critical approach to their own material is widespread in writing about the group. Willis goes so far as to say about "Street Fighting Man" that "I know Jagger understands the ironies involved and has no illusions about himself." $7^{2}$ This seems to mean that while the words of the song may suggest a cop-out, Jagger knows that, therefore he's not really copping out.

69 Marcus, "A Singer," 95.

70 Lydon, "Would You Want Your Sister," 68.

${ }^{71}$ Richard Merton, "Comment (Reply to 'Stones,' by Alan Beckett)," in The Age of Rock: Sounds of the American Cultural Revolution, ed. Jonathan Eisen (New York: Vintage Books, 1969), 116. The italics are Merton's. See similar remarks by Christgau, "Rock 'n' Revolution," 226-27. Michael Parsons explicitly challenges Merton in "Rolling Stones," in The Age of Rock, ed. Eisen, $118-20$.

$7^{2}$ Willis, "The Big Ones," 61. 
Sharply reflected in the critical reception of "Revolution" was the split between two strains of anti-Establishment thinking in the late 196os, between the New Left and what Richard Neville called the "psychedelic Left." 73 The New Left were the political activists, whose rhetoric had sharpened and whose willingness to become involved in violent confrontation had increased as the decade had progressed. The "psychedelic Left" were the hippies, the social drop-outs and communeorganizers. They were the people who felt that the appropriate response to social and political oppression was a personal transcendence, a search for a purer and less compromised way of living. In "Revolution" Lennon clearly aligns himself with the latter ("change your head," "free your mind instead"); small wonder that those in the New Left, the politically militant side, screamed in outrage, especially because they had been convinced up to that point that he was one of them.74 (Again Marcus's words: "We felt tricked, because we had expected the Beatles to be our spokesmen (whoever 'we' were), to say what we wanted to hear.") And the timing of Lennon's message, if he aimed to be understood sympathetically, could not have been worse. As we have seen, 1968 was a turning point for the social and political activism of the decade: It was the year when nonviolence seemed to have exhausted itself and when "the Establishment" seemed determined to meet nonviolent protest with violent repression. The brutality at the Chicago convention in August was the final blow to many people's hopes for nonviolent action. And of course, "Revolution" was released in the United States on the first day of the convention. It is no surprise that so many on the Left felt abandoned by their hero at a crucial moment.

Lennon's own ambivalence about "Revolution," his own multiple changes of mind, have made room in the years since 1968 for very different interpretations of the song and its role in his political evolution. For Jon Wiener, writing in 1984, "'Revolution' cast the personal and political as antagonistic forms of liberation"-in so doing, according to Wiener, it represented a foolish and premature rejection of New Left political activism, later corrected by such songs as "Working Class Hero" (1970) and by Lennon's outspoken political stances in the early 1970s.75 A decade later, Ian MacDonald saw "Revolution" in just the opposite way, as an informed and principled rejection of political violence, marred only slightly by some moments of ambivalence ("count me out-in") and later vindicated by historical events. He approvingly

73 Richard Neville, Play Power: Exploring the International Underground (New York: Random House, 1970), 105 .

74 See ibid., 105-6, and Wiener, Come Together, 81-84.

75 Wiener, Come Together, 7,63 . 
THE JOURNAL OF MUSICOLOGY

points out that Lennon's "rejection of 'minds that hate' and dry demand to be shown 'the plan' shows an intuitive grasp of the tangled issue of ideology." $7^{6}$ At the end of 1968, Lennon's position was attacked in Black Dwarf, a Marxist underground paper in London. In "An open letter to John Lennon," John Hoyland wrote that "what we're up against is not nasty people, not neurosis, not spiritual undernourishment. What we're confronted with is a repressive, vicious, authoritarian system. A system which is inhuman and immoral. ... It must be destroyed, ruthlessly." In reply Lennon stood firm. "I'll tell you what's wrong with the world: people-so do you want to destroy them? Until you/we change our heads-there's no chance. Tell me of one successful revolution. Who fucked up communism, christianity, capitalism, buddhism, etc.? Sick heads, and nothing else."77 In MacDonald's words, by the time of the final "Revolution" recording Lennon

was committed to peace, and in effect, already pledged to the series of Dadaish demonstrations on its behalf [created with Yoko Ono] which would eventually bring the derision of both Left and Right down on him, driving him into isolation.... Up against a hip consensus, Lennon stuck to his guns for a year and a half . . . before finally capitulating in New York [in the early 1970s] by donning a Mao badge and regulation black beret and leather gloves. $7^{8}$

But Lennon in turn later refuted his Maoist political phase. In his last interview in 1980 he expressed again the position argued by "Revolution." "The lyrics stand today. They're still my feeling about politics: I want to see the plan. . . . Count me out if it's for violence. Don't expect me on the barricades unless it is with flowers." 79 MacDonald archly concludes that "Tiananmen Square, the ignominious collapse of Soviet communism, and the fact that most of his radical persecutors of 196870 now work in advertising have belatedly served to confirm [Lennon's] original instincts." 80 The notoriously self-contradictory Lennon is still a contested figure for music critics and historians of the 6os; and the twists and turns of the "Revolution" story illustrate vividly the complexities of both his art and its reception.

Trinity College

\footnotetext{
$7^{6}$ MacDonald, Revolution in the Head, 227.

77 The exchange is excerpted and discussed in Wiener, Come Together, 81-84.

${ }_{7}^{8}$ MacDonald, Revolution in the Head, 227, 237.

79 Sheff and Golson, All We Are Saying, 187. Italics are in the original.

8o MacDonald, Revolution in the Head, 238.
} 